\title{
Rapeseed Oil as Renewable Resource for Polyol Synthesis
}

\author{
Uldis Stirna $^{1}$, Anda Fridrihsone ${ }^{2}$, Marija Misane ${ }^{3}$, Dzintra Vilsone ${ }^{4},{ }^{1-4}$ Latvian State Institute of Wood Chemistry
}

\begin{abstract}
Vegetable oils are one of the most important platform chemicals due to their accessibility, specific structure of oils and low price.

Rapeseed oil (RO) polyols were prepared by amidization of RO with diethanolamine (DEA). To determine the kinetics of amidization reaction, experiments were carried out. Fourier transform infrared spectroscopy (FTIR), differential scanning calorimetry (DSC), amine (NH) value was determined. Group contribution method by Fedor's was used to calculate solubility parameters, van der Waals volume was calculated by Askadskii. Obtained polyol`s $\mathrm{OH}$ and $\mathrm{NH}$ value are from $304 \mathrm{up}$ to $415 \mathrm{mg}$ $\mathrm{KOH} / \mathrm{g}$. RO polyols synthesis meets the criteria of "green chemistry".

In the present study, reaction of RO amidization with DEA was investigated, as well as optimum conditions for polyol synthesis was established to obtain polyols for polyurethane production. Calculations of solubility parameter and cohesion energy density were calculated, as RO polyols will be used as side chains in polymers, and solubility parameter will be used to explain properties of polymers.
\end{abstract}

Keywords - amidization, esterification, NH value determination, polyols, rapeseed oil, renewable resources, and vegetable oil

\section{INTRODUCTION}

Petrochemical resources, used intensively in the chemical industry worldwide, are limited and are rapidly decreasing. The chemical industry is making big efforts to find alternatives for petrochemical raw materials, and environmental pressures demand cleaner processes which result in active development of "green" chemistry - using cleaner processes, less energy and renewable materials $[1,2$, 3].

Increasing attention is paid to obtaining polymer materials from renewable resources. Natural oil-derived polyols have been considered as an alternative for petroleum-based polyols. Extended usage of different vegetable oils for various applications is important not only because of diminishing petroleum resources, an important aspect is also environmental protection and sustainability.

Vegetable oils are triglycerides of fatty acids, which have a number of excellent properties, so they could be utilized in producing valuable polymeric materials and, probably, will become a potential bio-renewable feedstock for polyurethanes $[4,5,6,7]$. Vegetable oils consist of triglycerides which are made up of three fatty acids joined to a glycerol backbone (Figure 1). Most of the common oils contain fatty acids that vary from 14 to 22 carbons in length, with 0 to 3 double bonds per fatty acid, popular fatty acids are with chain lengths of C16 - C18 [1, 5, 8].

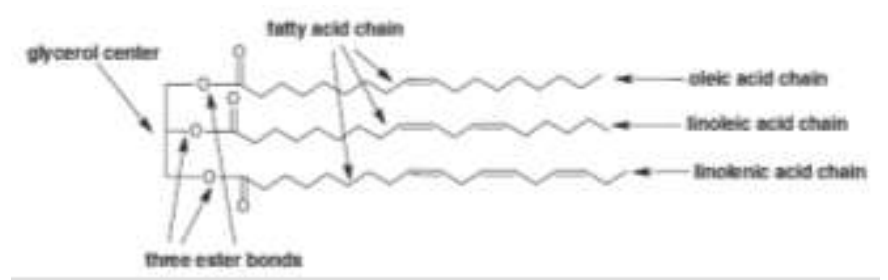

Fig. 1. The triglyceride chain containing three fatty acid chains joined by a glycerol center [5].

Polyols play an important role in polyurethane industry. To obtain polyurethane materials from vegetable oil, hydroxyl groups are necessary for the reactions with isocyanate groups that result in urethane linkages. To obtain polyurethane materials from vegetable oil, hydroxyl groups are necessary for the reactions with isocyanate groups that result in urethane linkages. Unfortunately, there are no hydroxyl groups in RO triacylglycerol structures of saturated and unsaturated fatty

TABLE I

FATTY ACID COMPOSITION (\%) OF VARIOUS PLANT OILS [ADAPTED FROM 4]

\begin{tabular}{|l|c|c|c|c|c|c|c|c|c|c|c|c|}
\hline $\begin{array}{l}\text { Carbon atoms: } \\
\text { Double bonds }\end{array}$ & $14: 0$ & $16: 0$ & $16: 1$ & $18: 0$ & $18: 1$ & $18: 2$ & $18: 3$ & $20: 0$ & $20: 1$ & $22: 0$ & $22: 1$ & $24: 0$ \\
\hline Rapeseed oil & 0.1 & 4.0 & 0.3 & 1.8 & 60.9 & 21.0 & 8.8 & 0.7 & 1.0 & 0.3 & 0.7 & 0.2 \\
\hline Soybean oil & 0.1 & 10.6 & 0.1 & 4.0 & 23.3 & 53.7 & 7.6 & 0.30 & 0 & 0.3 & 0 & 0 \\
\hline Linseed oil & 0 & 6.0 & 0 & 4.0 & 22.0 & 16.0 & 52.0 & 0.5 & 0 & 0 & 0 & 0 \\
\hline Castor oil & 0 & 2.0 & 0 & 1.0 & 7.0 & 3.0 & 0 & 0 & 0 & 0 & 0 & 0 \\
\hline Palm oil & 1.0 & 44.4 & 0.2 & 4.1 & 39.3 & 10.0 & 0.4 & 0.3 & 0 & 0.1 & 0 & 0 \\
\hline Sunflower oil & 0.1 & 7.0 & 0.1 & 4.5 & 18.7 & 67.5 & 0.8 & 0.4 & 0.1 & 0.7 & 0 & 0 \\
\hline Palm kernel oil & 16.2 & 8.4 & 0 & 2.5 & 15.3 & 2.3 & 0 & 0.1 & 0.1 & 0 & 0 & 0 \\
\hline Corn oil & 0.1 & 10.9 & 0.2 & 2.0 & 25.4 & 59.6 & 1.2 & 0.4 & 0 & 0.1 & 0 & 0 \\
\hline
\end{tabular}


acids; hence, there is a need for chemically introduced hydroxyl groups onto RO triacylglycerol's [9]. Rapeseed oil or canola oil, as called in North America, is derived from Brassica napus $L$. oilseeds. RO mainly consists of unsaturated fatty acids - oleic, linoleic acid, linolenic acid and other saturated and unsaturated fatty acids (Table I).

The literature presents several chemical pathways to introduce hydroxyl functionality into the triacylglycerol's of vegetable oils containing unsaturated fatty acids [7, 10, 11, 12].

Natural oil polyols with primary hydroxyl groups can be synthesized by vegetable oil reacting with amino alcohols [13].

The focus of this research is to determine kinetics of RO amidization with DEA and to understand what changes happen to polyol when it is stored for a longer period of time. Calculation on solubility parameters $(\delta)$ of vegetable oils and fatty acids and cohesion energy density $\left(\mathrm{e}_{\mathrm{coh}}\right)$, as well as van der Waals volume $\left(\mathrm{V}_{\mathrm{w}}\right)$ of fatty acid, were carried out.

\section{II.EXPERIMENTAL PROCEDURES}

\section{A. Materials}

Rapeseed oil (specifications: iodine value $=117 \mathrm{I}_{2} \mathrm{mg} / 100$ g sample, acid value $=2.1 \mathrm{mg} \mathrm{KOH} / \mathrm{g}$, saponification value $=$ $192 \mathrm{mg} \mathrm{KOH} / \mathrm{g}$ sample) was obtained from Iecavnieks, Latvia. The fatty acid composition was as follows: $62.4 \%$ oleic acid, $20.6 \%$ linoleic acid, $9.3 \%$ linolenic acid, $4.7 \%$ palmitic acid and $0.3 \%$ other fatty acids. Diethanolamine $99.2 \%$ (Huntsman, The Netherlands) was used as purchased.

\section{B. Synthesis of rapeseed oil polyols}

Polyols of RO were prepared by amidization. The reaction was carried out in a three neck $1.0 \mathrm{~L}$ thermo resistant glass reaction flask submerged in a silicone bath. The reaction flask was equipped with a mechanical stirrer, a thermometer, a cooler and an argon inlet tube. RO (1 M) was weighed and heated to $140 \pm 5{ }^{\circ} \mathrm{C}$, then $0.15 \mathrm{wt} \%$ zinc acetate as catalyst was added with stirring and during the next $15 \mathrm{~min} 139 \mathrm{~g} \mathrm{(2.1}$ $\mathrm{M}$ ) of preheated (to $70{ }^{\circ} \mathrm{C}$ ) DEA was added. The reaction of amidization was carried out for $4-5 \mathrm{~h}$. The end of reaction is tested by solubility of obtained product in ethanol at volume ratio $1: 1$. If the RO polyol dissolves in ethanol, it is the end of the amidization. If needed, vacuum distillation at $200 \mathrm{mmHg}$ is used to remove water from synthesis, for example, if polyol is used for obtaining polyurethane films. RO diethanolamides at different molar ratios were prepared as described.

\section{NH value determination}

$\mathrm{NH}$ value was determined by titration of the sample $(0.3-0.4 \mathrm{~g}$ RO polyol) in ethanol solution with standardized $0.1 \mathrm{~N} \mathrm{HCl}$ by using bromoresol green solution as an indicator.

\section{FTIR Spectra Analysis}

FTIR spectra measurements were made on a Perkin-Elmer spectrometer, Model: Spectrum One FTIR Spectrometer. FTIR spectroscopy data were used to monitor functional groups of the synthesized products.

\section{E. Differential scanning calorimetry}

Calorimetric measurements (DSC) were made on a differential scanning calorimeter Mettler Toledo 823 . About $3 \mathrm{mg}$ of sample were used to analyse the course of reaction. Experiments were carried out isothermally at $120^{\circ} \mathrm{C}, 140{ }^{\circ} \mathrm{C}$ and $160{ }^{\circ} \mathrm{C}$ for up to $180 \mathrm{~min}$. The results were plotted as a conversion degree against time in minutes.

\section{RESULTS AND DISCUSSION}

To characterize RO solubility parameter, cohesion energy density and van der Waals volume were calculated. Solubility parameter and cohesion energy density were calculated by Fedor`s group contribution method [14], van der Waals volume by Askadskii $[15,16]$. The results are shown in Table II.

TABLE II

SOLUBILITY PARAMETERS, COHESION ENERGY DENSITY, VAN DER WAALS VOLUME OF SOME VEGETABLE OILS

\begin{tabular}{|l|c|c|c|}
\hline $\begin{array}{l}\text { Vegetable } \\
\text { oil }\end{array}$ & $\begin{array}{c}\text { Solubility } \\
\text { parameter, }^{\left(\mathbf{c a l}_{\mathbf{c}} \mathbf{c m}^{\mathbf{3}}\right)^{1 / 2}}\end{array}$ & $\begin{array}{c}\text { Cohesion } \\
\text { energy density, }^{\left(\mathbf{c a l}_{\mathbf{c m}}\right)^{\mathbf{1 / 2}}}\end{array}$ & $\begin{array}{c}\text { van der Waals } \\
\text { volume, } \mathbf{~ c m}^{\mathbf{3}} / \mathbf{m o l}\end{array}$ \\
\hline $\begin{array}{l}\text { Rapeseed } \\
\text { oil }\end{array}$ & 8.94 & 80.00 & 184.02 \\
\hline $\begin{array}{l}\text { Soybean } \\
\text { oil }\end{array}$ & 8.96 & 80.28 & 177.90 \\
\hline Linseed oil & 8.99 & 80.83 & 176.54 \\
\hline Castor oil & 10.03 & 100.52 & 187.23 \\
\hline
\end{tabular}

For soybean oil, the calculated solubility parameter $8.94\left(\mathrm{cal} / \mathrm{cm}^{3}\right)^{1 / 2}$ is close to $(\delta)$ calculated by King by inverse gas chromatography [17].

Castor oil has slightly higher solubility parameter and cohesion energy density because ricinoleic acid contains $\mathrm{OH}$ group which has a much higher energy of vaporization which results in higher cohesion energy density and solubility parameter, respectively.

Also solubility parameter for DEA was calculated. It is $13.45\left(\mathrm{cal} / \mathrm{cm}^{3}\right)^{1 / 2}$. There is a noticeable difference between solubility parameters of RO and DEA, because of that, RO amidization reaction initially occurs at heterogeneous phase.

The composition of vegetable oil and fatty acid content differs within few per cent, depending on weather and other factors. Solubility parameters of unsaturated and saturated fatty acid radicals, attached to glycerol backbone, were calculated (Table III).

As seen in Table III, with the increasing number of $\mathrm{CH}_{2}$ groups in a fatty acid molecule, the solubility parameter decreases. The solubility parameter of fatty acid radicals plays an important role because synthesized polyols will be used as side chains in polymers. The value of the solubility parameter will affect the effectiveness of solubility, provide better reaction with foaming agents, like pentane $(\delta=7.1$ $\left.\left(\mathrm{cal} / \mathrm{cm}^{3}\right)^{1 / 2}\right)$ and freon $\left(\delta=7.25 \quad\left(\mathrm{cal} / \mathrm{cm}^{3}\right)^{1 / 2}\right)$, because their solubility parameters are very close [18]. 
TABLE III

SOLUBILITY PARAMETER OF SATURATED AND UNSATURATED FATTY ACID RADICALS

\begin{tabular}{|l|l|c|c|l|c|}
\hline Name & Formula & $\begin{array}{c}\text { Molar } \\
\text { mass, } \\
\text { g/mol }\end{array}$ & $\begin{array}{c}\text { Carbon atoms: } \\
\text { double bond }\end{array}$ & Structural formula & $\boldsymbol{\delta},\left(\mathbf{c a l} / \mathbf{c m}^{3}\right)^{\mathbf{1} 2}$ \\
\hline Myristic acid & $\mathrm{C}_{14} \mathrm{H}_{27} \mathrm{O}_{2}$ & 227.37 & $14: 0$ & $\mathrm{CH}_{3}\left(\mathrm{CH}_{2}\right)_{12} \mathrm{COO}$ & 8.95 \\
\hline Palmitic acid & $\mathrm{C}_{16} \mathrm{H}_{31} \mathrm{O}_{2}$ & 255.42 & $16: 0$ & $\mathrm{CH}_{3}\left(\mathrm{CH}_{2}\right)_{14} \mathrm{COO}$ & 8.90 \\
\hline Palmitoleic acid & $\mathrm{C}_{16} \mathrm{H}_{29} \mathrm{O}_{2}$ & 253.41 & $16: 1$ & $\mathrm{CH}_{3}\left(\mathrm{CH}_{2}\right)_{5} \mathrm{CH}=\mathrm{CH}\left(\mathrm{CH}_{2}\right)_{7} \mathrm{COO}$ & 8.93 \\
\hline Stearic acid & $\mathrm{C}_{18} \mathrm{H}_{35} \mathrm{O}_{2}$ & 283.48 & $18: 0$ & $\mathrm{CH}_{3}\left(\mathrm{CH}_{2}\right)_{16} \mathrm{COO}$ & 8.87 \\
\hline Oleic acid & $\mathrm{C}_{18} \mathrm{H}_{33} \mathrm{O}_{2}$ & 281.46 & $18: 1$ & $\mathrm{CH}_{3}\left(\mathrm{CH}_{2}\right)_{7} \mathrm{CH}=\mathrm{CH}_{(}\left(\mathrm{CH}_{2}\right)_{7} \mathrm{COO}$ & 8.89 \\
\hline Linoleic acid & $\mathrm{C}_{18} \mathrm{H}_{31} \mathrm{O}_{2}$ & 279.45 & $18: 2 . \mathrm{n}-6$ & $\mathrm{CH}_{3}\left(\mathrm{CH}_{2}\right)_{4} \mathrm{CH}=\mathrm{CHCH}_{2} \mathrm{CH}=\mathrm{CH}\left(\mathrm{CH}_{2}\right)_{7} \mathrm{COO}$ & 8.91 \\
\hline Linolenic acid & $\mathrm{C}_{18} \mathrm{H}_{29} \mathrm{O}_{2}$ & 277.43 & $18: 3 . \mathrm{n}-3$ & $\mathrm{CH}_{3} \mathrm{CH}_{2} \mathrm{CH}=\mathrm{CHCH} \mathrm{CH}_{2} \mathrm{CHCH} \mathrm{CH}_{2} \mathrm{CH}(\mathrm{CH})_{7} \mathrm{COO}$ & 8.93 \\
\hline Ricinoleic acid & $\mathrm{C}_{18} \mathrm{H}_{33} \mathrm{O}_{3}$ & 297.46 & $18: 2$ & $\mathrm{CH}_{3}\left(\mathrm{CH}_{2}\right)_{5} \mathrm{CH}(\mathrm{OH}) \mathrm{CH}_{2} \mathrm{CH}=\mathrm{CH}\left(\mathrm{CH}_{2}\right)_{7} \mathrm{COO}$ & 10.18 \\
\hline Arachidic acid & $\mathrm{C}_{20} \mathrm{H}_{39} \mathrm{O}_{2}$ & 311.53 & $20: 0$ & $\mathrm{CH}_{3}\left(\mathrm{CH}_{2}\right)_{18} \mathrm{COO}$ & 9.00 \\
\hline Eicosenoic acid & $\mathrm{C}_{20} \mathrm{H}_{37} \mathrm{O}_{2}$ & 309.52 & $20: 1$ & $\mathrm{CH}_{3}\left(\mathrm{CH}_{2}\right)_{7} \mathrm{CH}=\mathrm{CH}\left(\mathrm{CH}_{2}\right)_{9} \mathrm{COO}$ & 8.86 \\
\hline Behenic acid & $\mathrm{C}_{22} \mathrm{H}_{44} \mathrm{O}_{2}$ & 339.59 & $22: 0$ & $\mathrm{CH}_{3}\left(\mathrm{CH}_{2}\right)_{20} \mathrm{COO}$ & 8.84 \\
\hline Erucic acid & $\mathrm{C}_{22} \mathrm{H}_{41} \mathrm{O}_{2}$ & 337.57 & $22: 1$ & $\mathrm{CH}_{3}\left(\mathrm{CH}_{2}\right)_{7} \mathrm{CH}=\mathrm{CH}\left(\mathrm{CH}_{2}\right)_{11} \mathrm{COO}$ & 8.83 \\
\hline Lignoceric acid & $\mathrm{C}_{24} \mathrm{H}_{47} \mathrm{O}_{2}$ & 367.64 & $24: 0$ & $\mathrm{CH}_{3}\left(\mathrm{CH}_{2}\right)_{22} \mathrm{COO}$ & 8.82 \\
\hline
\end{tabular}

RO polyols were prepared as described in $B$. Synthesis of rapeseed oil polyols. Obtained RO polyols are characterized by hydroxyl value and $\mathrm{NH}$ value (Table IV).

TABLE IV

CHARASTERIZATION OF OBTAINED RAPESEED OIL POLYOLS

\begin{tabular}{|l|c|c|}
\hline Polyol & $\begin{array}{c}\text { Molar } \\
\text { ratio } \\
\text { DEA/RO }\end{array}$ & $\begin{array}{c}\text { Polyols OH+NH } \\
\text { value, }(\mathbf{m g} \text { KOH/g) }\end{array}$ \\
\hline DEA-RO & $2.07: 1$ & 304 \\
\hline DEA-RO & $2.10: 1$ & 311 \\
\hline DEA-RO & $2.50: 1$ & 360 \\
\hline DEA-RO & $2.9: 1$ & 415 \\
\hline
\end{tabular}

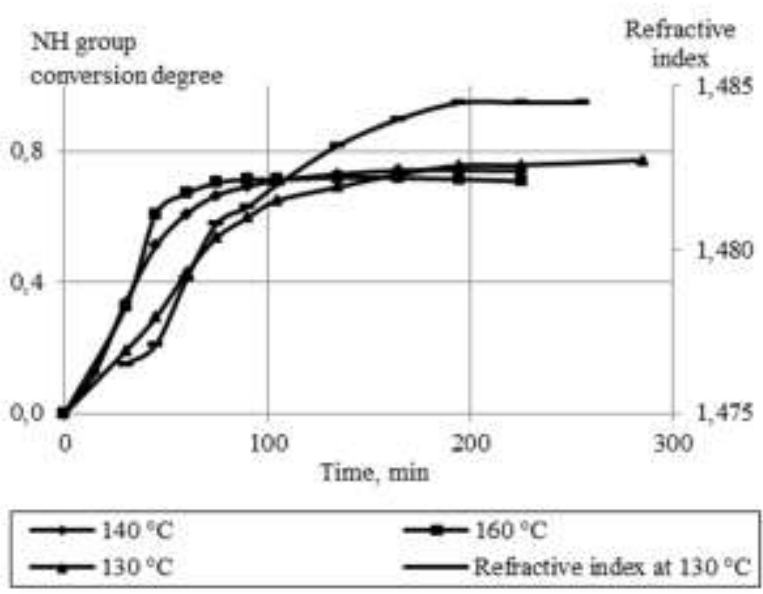

Fig. 2. NH group conversion during RO polyol`s synthesis.
To determine kinetics of RO amidization with DEA, RO polyols were synthesized by reacting RO with DEA at a molar ratio of $1: 2.9 \mathrm{M}$. The kinetics of amidization was investigated at three temperatures $-130{ }^{\circ} \mathrm{C}, 140{ }^{\circ} \mathrm{C}$ and 160 ${ }^{\circ} \mathrm{C}$. The course of reaction was followed and analysed using NH groups' degree of conversion and FTIR spectroscopy data.

Figure 2 shows that during the first hour $\mathrm{NH}$ group degree of conversion reaches 0.6 , but then the reaction slow down.

At the temperatures of $130{ }^{\circ} \mathrm{C}, 140{ }^{\circ} \mathrm{C}$ and $160{ }^{\circ} \mathrm{C}, \mathrm{NH}$ groups' conversion degree reached $77 \%, 74 \%$ and $72 \%$, respectively. Also refractive index was controlled during the synthesis and refractive index correlates with increasing $\mathrm{NH}$ groups degree on conversion. Low $\mathrm{NH}$ group conversion at the end of the reaction could be explained by thermal rearrangement of the amide to amino ester (Figure 3) [19].

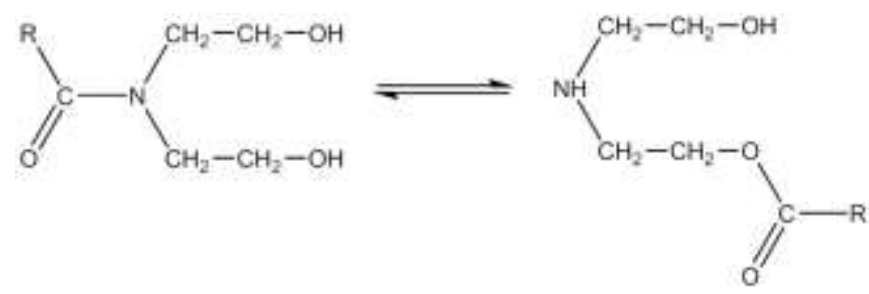

Fig. 3. Reaction products of RO amidization with diethanolamine, where $\mathrm{R}-\mathrm{C}_{12}-\mathrm{C}_{22}$ are unsaturated and saturated fatty acid radicals.

To test the hypothesis that both amidization and transesterification processes progressed in parallel during the RO diethanolamide synthesis, polyols were stored at room temperature for five to six months and during this period $\mathrm{NH}$ value was monitored (Figure 4). 
As seen in Figure 4, the $\mathrm{NH}$ value of the obtained $\mathrm{RO}$ diethanolamides decreases, when they are stored at room temperature for a long time. The greater $\mathrm{NH}$ value at the end of the storage period is for the polyols that are synthesized at higher RO and DEA molar ratios.

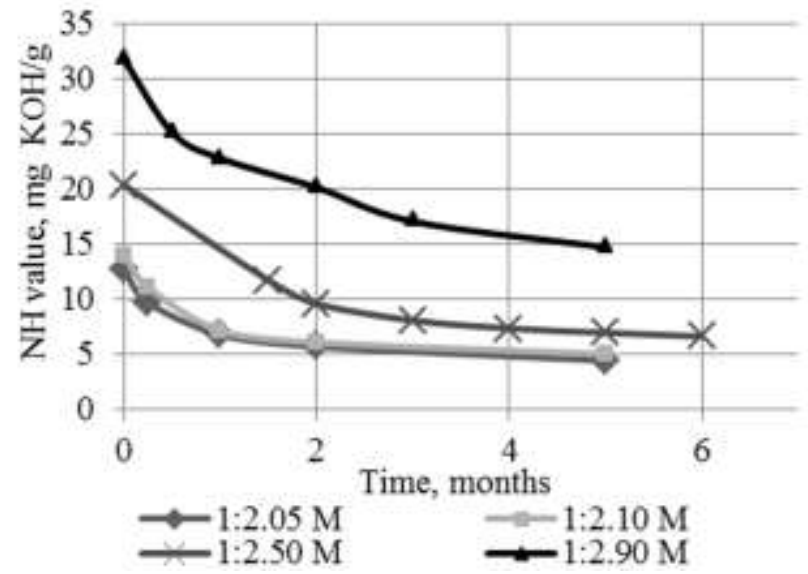

Fig. 4. Changes in $\mathrm{NH}$ groups during $\mathrm{RO}$ polyol's storage depending on time and RO:DEA molar ratio.

The decreasing of the $\mathrm{NH}$ value indicated that there might be equilibrium between diethanolamide and amine group containing compounds. To test the hypothesis whether there is equilibrium between $\mathrm{RO}$ diethanolamide and amine group containing compounds, we used RO polyol which was synthesized at RO and DEA molar ratio 1.0:2.5 $\mathrm{M}$ and stored for 4 years at room temperature. The polyol was reheated at $140{ }^{\circ} \mathrm{C}$ and $160{ }^{\circ} \mathrm{C}$ and $\mathrm{NH}$ value was monitored (Figure 5)

\section{$\mathrm{NH}$ value, $\mathrm{mg} \mathrm{KOH} / \mathrm{g}$}

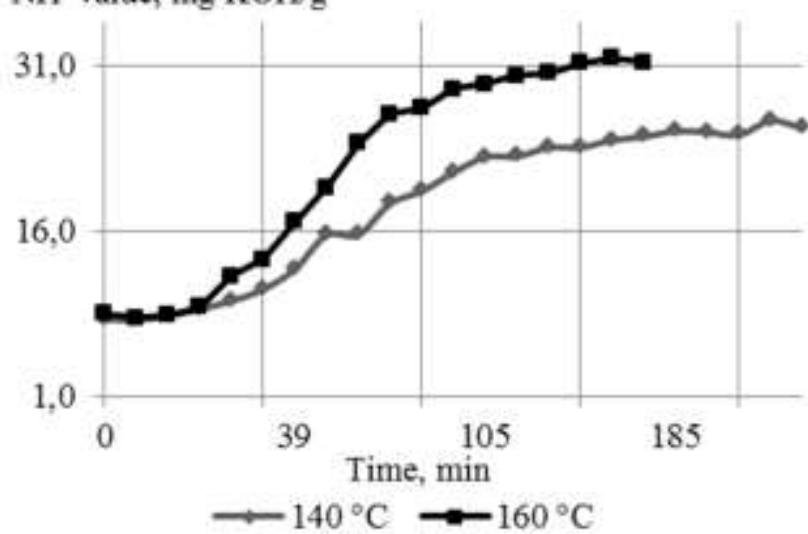

Fig. 5. Change in $\mathrm{NH}$ value versus time reheating $\mathrm{RO}$ diethanolamide preserved for 4 years, reheated at $140{ }^{\circ} \mathrm{C}$ and $160{ }^{\circ} \mathrm{C}$.

As seen in Figure 5, RO polyols $\mathrm{NH}$ value was $7 \mathrm{mg} \mathrm{KOH} / \mathrm{g}$ after storage, after reheating it increased to $27 \mathrm{mg} \mathrm{KOH} / \mathrm{g}$ at $140{ }^{\circ} \mathrm{C}$, at $160{ }^{\circ} \mathrm{C}$ increased to $32 \mathrm{mg}$ $\mathrm{KOH} / \mathrm{g}$. The results prove that there is equilibrium between fatty acid amino esters and diethanolamides when RO is amidizated with DEA.
The kinetics of RO amidization was investigated also using the Fourier transform infrared spectroscopy data (Figure 6).

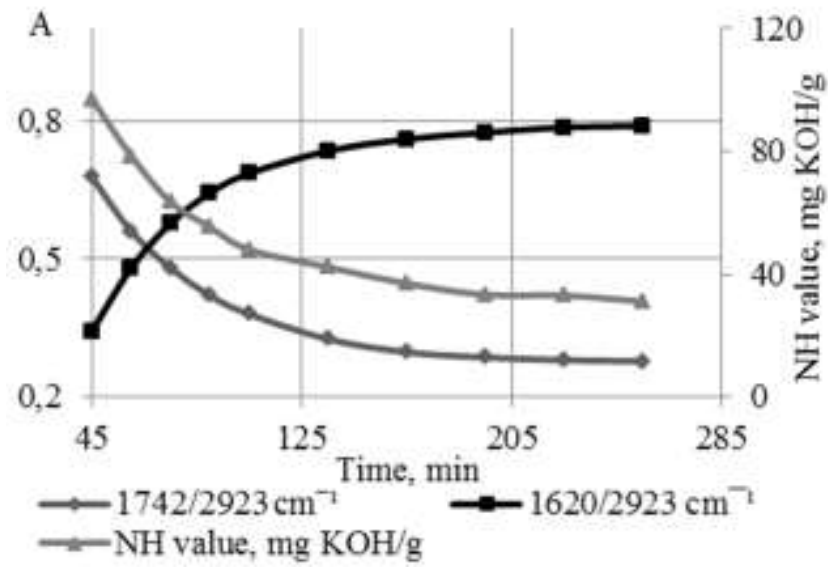

Fig. 6. The ratio of $\mathrm{A}_{1742} / \mathrm{A}_{2923}$ and $\mathrm{A}_{1620} / \mathrm{A}_{29323}$ and $\mathrm{NH}$ value during diethanolamide synthesis versus time.

The relative intensity of $\mathrm{C}=\mathrm{O}$ groups decreases at $1739 \mathrm{~cm}^{-1} / 2923 \mathrm{~cm}^{-1}$, while the $\mathrm{C}=\mathrm{O}$ absorption intensity at $1620 \mathrm{~cm}^{-1} / 2923 \mathrm{~cm}^{-1}$, characteristic of tertiary amide, increases. The results confirm that the NH group degree of conversion reaches $77 \%$ for the synthesis at $130{ }^{\circ} \mathrm{C}$. The $\mathrm{NH}$ value correlates with decreasing intensity of $\mathrm{C}=\mathrm{O}$ groups at $1739 \mathrm{~cm}^{-1} / 2923 \mathrm{~cm}^{-1}$. The $\mathrm{NH}$ group conversion degree is expected to be similar also for the synthesis at $140^{\circ} \mathrm{C}$ and $160^{\circ} \mathrm{C}$.

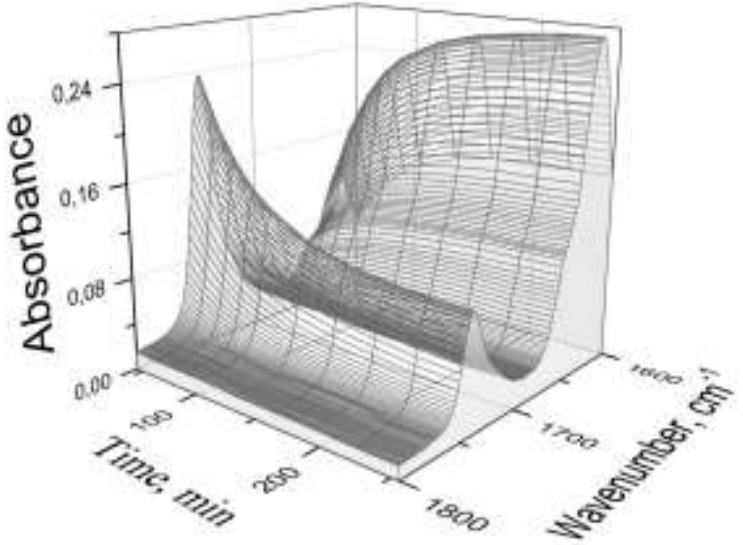

Fig. 7. Time resolved FTIR spectra during polyol`s synthesis.

The three dimensional plot shows $\mathrm{C}=\mathrm{O}$ groups decreasing rapidly during the first 100 minutes and peek at $1620 \mathrm{~cm}^{-1}$, characterizing $\mathrm{C}=\mathrm{O}$ of tertiary amide, group increasing.

Vegetable oil amidization and transesterification was also analyzed by using differential scanning calorimetry (DSC). Since DEA solubility parameter significantly differs from RO solubility parameter, they form heterogeneous systems. For this reason, DSC experiments were made by using castor oil with DEA at molar ratio 1.0:2.9 $\mathrm{M}$ at $140{ }^{\circ} \mathrm{C}$. It was calculated from DSC curves 
that the process of castor oil amidization with DEA at 140 ${ }^{\circ} \mathrm{C}$ occurs with the enthalpy $14.53 \mathrm{cal} / \mathrm{g}$.

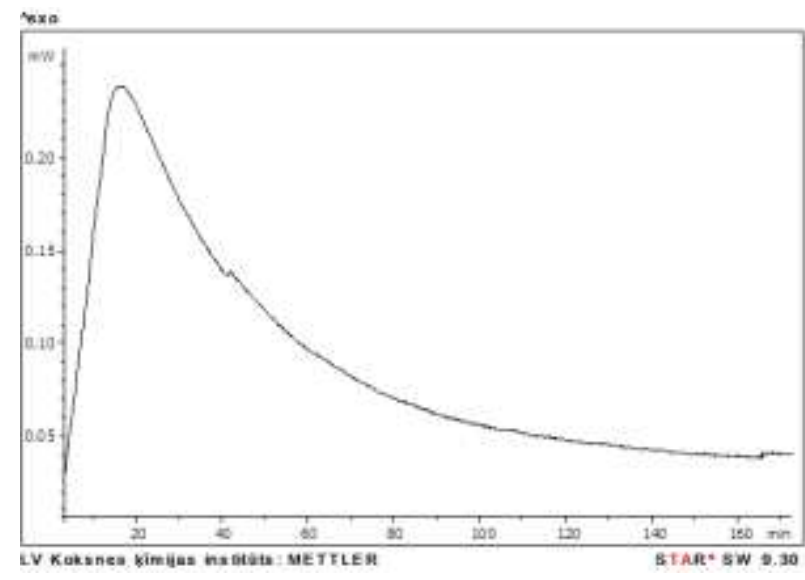

Fig. 8. DSC curve of castrol oil amidization with DEA.

\section{CONCLUSIONS}

Polyols obtained from RO amidization with DEA at different molar ratios are composed from fatty acid diethanolamide and amino esters. Using FTIR spectroscopy, changes in the concentration kinetics of tertiary amide and ester groups during polyols synthesis process have been established. Equilibrium shifts to fatty acid diethanolamide side, if the temperature of synthesis is lower, and also when polyols are stored. The process of RO polyols synthesis meets the criteria of green chemistry.

\section{ACKNOWLEDGMENT}

The work has been financed by the European Regional Development Fund.

Contract No 2DP/2.1.1.0/10/APIA/VIAA/054.

\section{REFERENCES}

1. Ionescu, M. Chemistry and Technology of Polyols for Polyurethanes. Shropshire: Rapra Technology Limited, 2005, 586 p.

2. Scrimgeour, C. Chemistry of fatty acids. In: Bailey's Industrial Oil and Fat Products. John Wiley \& Sons. Inc., 2005, vol. 6, p. 1-43.

3. Espinosa, L.M., Meier, M.A.R. Plant oils: The perfect renewable resource for polymer science. European Polymer Journal, 2011, vol. 47, N 5, p. 837-852.

4. Petrovic, Z.S. Polyurethanes from vegetable oils. Polymer Reviews, 2008, vol. 48, N 1, p. 109-155.

5. Sharma, V., Kundu, P.P. Addition polymers from natural oils-A review. Progress in Polymer Science. 2006. vol. 31. N 11, p. 983 1008 .

6. Lligadas, G., Ronda, J.C., Galia, M., Cadiz, V. Oleic and Undecylenic Acids as Renewable Feedstocks in the Synthesis of Polyols and Polyurethanes. Polymers, 2010, vol. 2, p. 440-453.

7. Guo, A., Petrovic, Z. Vegetable oil based polyols. In: Industrial Uses of vegetable oil. AOCS Publishing, 2005, p. 110-130.

8. Dyer, J.M., Stymne, S., Green, A.G., Carlsson, A.S. High-value oils from plants. The Plant Journal, 2008, vol. 54, N 4, p. 640-655.

9. Stirna, U., Fridrihsone, A., Lazdina, B., Misane, M., Vilsone, Dz. Structure and properties of rape seed oil and diethanolamine polyol and polyurethane on their base. In: International Conference "Renewable Wood and Plant Resources: Chemistry, Technology, Pharmacology, Medicine”. Saint-Petersburg, Russia, June 21-24, 2011. Abstracts. Saint-Petersburg, 2011, p. 216-217.
10. Ronda, J.C., Lligadas, G., Galia, M., Cadiz, V. Vegetable oils as platform chemicals for polymer synthesis. European Journal of Lipid Science and Technology, 2011, vol. 113, N 1, p. 46-58.

11. Saetung, A. Preparation of Polyurethane Foams from Hydroxytelechelic Oligoisoprenes. Ph.D.thesis. Pattani: Prince of Songkla University, 2008, p. 191.

12. Dumont, M.J. Polyurethanes Plastic Sheets and Foams Synthesized from Aromatic Triols. Ph.D.thesis. Alberta: University of Alberta, 2010, p. 119.

13. Stirna, U., Sevastyanova, I., Misane, M., Cabulis, U., Beverte, I. Structure and properties of polyurethane foams obtained from rape seed oil polyols. Proceedings of the Estonian Academy of Science, Chemistry, 2006, vol. 55, N 2, p. 101-110.

14. Fedors, R. F. A method for estimating both the solubility parameters and molar volumes of liquids. Polymer engineering and science, 1974, vol. 14, N 2, p. 147-154.

15. Askadskii, A.A. Influence of chemical structure on the properties of polymers. Pure and applied chemistry, 1976, vol.46, p. 19-27.

16. Аскадский, А.А., Матвеев, Ю.И. Химическое строение и физические свойства полимеров. Москва: издательцтво "Химия", 1983, 247 с.

17. King, J.W. Determination of the solubility parameter of Soybean oil by inverse gas chromatography. LWT - Food Science and Technology, 1995, vol. 28, N 2, p. 190-195.

18. Luthria, L.D. Oil extraction and analysis: critical issues and comparative studies. AOCS Press. 2004, 288 p.

19. Kroll, H., Nadeau, H. The Journal of the American Oil Chemists Society 1957. vol. 34. P. 323-326.

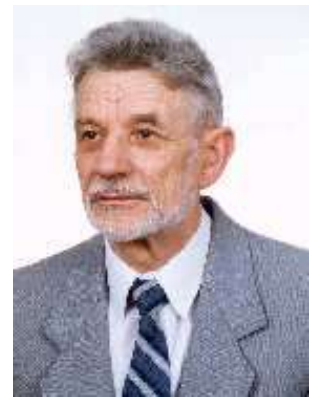

Uldis Stirna, Dr.habil.chem, graduated from the Riga Polytechnical Institute (nowadays Riga Technical University) and in 1970 received degree of the candidate of chemical sciences. In 1988 he successfully defended his dissertation at Institute of Wood Chemistry and received doctor's degree in chemistry. Since 1992 he has the degree of Dr.habil.chem. Uldis Stirna has been working at the Latvian State Institute of Wood Chemistry during all his life, and since 1989 he is the Head of the Polymer Laboratory. The main research field and interests are: chemistry of polyurethanes and technology, polyurethane foam and coatings from renewable raw materials, cryogenic heat isolation materials, bio-destructive polyurethanes from renewable raw material. He is the author of more than 200 scientific papers, 26 Inventions of the USSR, one of which is regarded as the Latvian all-time 10 most important inventions (see http://Latv/izgudrojumi/Ripors.asp) and 3 Latvian patents, one monograph.

Address: 27 Dzerbenes Str., LV-1006, Riga, Latvia

Phone: +371 67552581, Fax: +37167550635

E-mail: stirna@edi.lv

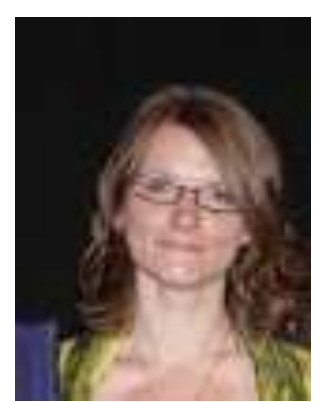

Anda Fridrihsone graduated from the Riga Technical University in 2010 and received Bachelor's degree in chemical engineering. At the moment she continues studies at RTU to receive Master's degree in Environmental Science. She is part of scientific staff - an engineer - at the Polymer Laboratory of the Latvian State Institute of Wood Chemistry. The main research field is obtaining polyurethanes from renewable resources - vegetable oils. Previously she was employed by the largest manufacturer of bio cosmetics and

perfumery in the Baltics - Dzintars.

E-mail: anda.fridrihsone@gmail.com 


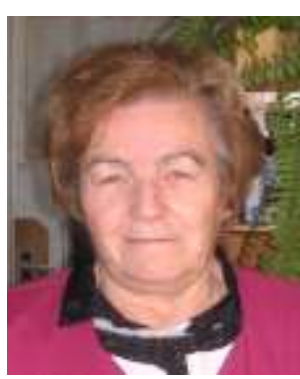

Dzintra Vilsone, Dr.chem, graduated from the Latvian University Chemistry Faculty in 1965. In 1976 she received degree of the candidate of chemical sciences; later in 1992 she received doctor of chemistry degree. Since 1964 she has been working at the Latvian State Institute of Wood Chemistry. The main research area is thermal properties of polyurethane materials. She is the author of more than 30 publications, 8 copyrights, 5 Latvian E-mail: dzivi@edi.lv patents and 1 monograph.

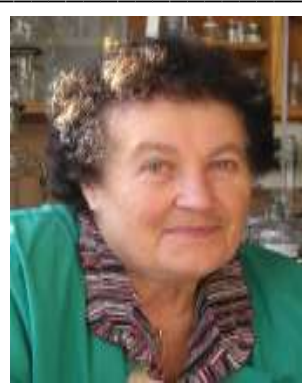

Phone: +37167552581
Marija Misane, graduated from the Riga Polytechnical Institute (nowadays Riga Technical University) in 1971 and she has engineer degree in technology of processing plastics. M.Misane has been scientific staff of the Polymer Laboratory at the Latvian State Institute of Wood Chemistry since 1971. The main research area is polyol synthesis of renewable materials - different vegetable oils and tall oil, as well as analysis of polyols. She is the author of more than 30 publications, 1 patent and 4 copyrights.

Uldis Stirna, Anda Fridrihsone, Marija Misāne, Dzintra Vilsone. Rapšu ellla kā atjaunojama izejviela poliolu sintēzei.

Aktualizējoties vides ilgtspējības jautājumiem un strauji samazinoties fosilo resursu krājumiem, ķīmijas industrija meklē jaunus veidus, kā iegūt izejvielas no atjaunojamiem resursiem. Dažādas augu elı̧as tiek uzskatītas par vienu no vissvarīgākajām atjaunojamo izejvielu klasēm, jo tām piemīt pievilcīgas fizikāli ķīmiskās īpašības, plaši pieejama, salīdzinoša zema cena.

Rapšu ellas polioli, kas ir izejviela poliuretānu ieguvei, tika iegūti funkcionalizējot rapšu ellı - ievadot tajā hidroksilgrupas ar amidizācijas reakcijas palīdzību. Polioli tika sintezēti rapšu ellıai reaǵējot ar dietanolamīnu dažādās molārās attiecībās no 1:2.05 - $2.9 \mathrm{M}$ pie $140{ }^{\circ} \mathrm{C}$. Iegūtos poliolus raksturo OH un NH skaitlis, kas ir robežās no $304-415 \mathrm{mg} \mathrm{KOH} / \mathrm{g}$ tiek iegūti polioli ar pirmējām hidroksilgrupām. Rapšu ellıas amidizācijas reakcijas kinētika tika pētīta pie molārās attiecības 1:2.9 M pie trīs dažādām temperatūrām $130{ }^{\circ} \mathrm{C}, 140{ }^{\circ} \mathrm{C}, 160{ }^{\circ} \mathrm{C}$. Kinētika tika pētīta izmantojot sekojošas metodes - FTIR spektroskopiju, DSC, NH grupu konversiju. NH grupu konversijas pakāpe pie dotajām temperatūrām attiecīgi bija $77 \%, 74 \%$ un $72 \%$. Noskaidrots, ka sintēzes gaitā estera C=O grupas relatīva absorbcijas intensitāte pie A1739/A2923 samazinās, kamēr amīda C=O grupas relatīva absorbcijas intensitāte pie A1620/A2923 palielinās. Noskaidrots, ka paralēli rapšu ellıas amidizācijas procesam, notiek arī tās pāresterifikācijas process, un rodas divi reakcijas produkti: rapšu ellıas amīds un amino grupu saturoša komponente. Poliolu ilgstoši glabājot, NH skaitlis samazinās no 29 līdz $8 \mathrm{mg} \mathrm{KOH/g} 6$ mēnešu laikā, līdzsvars nobīiās uz dietanolamīda pusi. Pēc tam poliolu sildot, NH skaitlis pieaug un līdzsvars nobīdās uz amīna grupu saturošo savienojuma pusi. 